\title{
Analisis Tingkat Produktivitas Petani Padi di Kelurahan Simarimbun
}

\section{Poltak Pardamean Simarmata}

Sekolah Tinggi Akuntansi Dan Manajemen Indonesia poltak.pardamean@sbm-itb.ac.id

\section{Muhammad Yunus}

Program Studi Manajemen, Program Studi Akuntansi m.yunus4994@gmail.com

\section{Putra Arys Arianto Manurung}

Program Studi Manajemen, Program Studi Akuntansi p.arys@gmail.com

This study aims to (1) know the factors that affect the productivity of wet
land paddy farming in Siantar Marimbunsub-district of Kelurahan
Simarimbun Regency (2) know the optimal using level of production
factors in rice farming in Siantar Marimbunsub-district, Kelurahan
Simarimbun regency. The analytical method used to analyze the factors
that influence productivity is Multiple Linear Regression Analysis, and
to determine the optimal level of use of production factors used NPM
approach. Based on the result of research, it is found that (1) the use of
Labor production factor (X1), Seed (X2), Urea Fertilizer (X3),Sp36
Fertilizer (X4), KCl Fertilizer (X5), Pesticide (X6) and Dummy influenced
84,42\% productivity of rice paddy that shown by coefficient of
determination (R2) of 0.8442 while the remaining $15.58 \%$ influenced by
other factors not described in this study. Regression results partially
obtained that the use of labor production factor (X1) did not significantly
affect productivity while the use of seed production factors (X2), fertilizer
(X3), and pesticide (X4) had a significant effect on productivity of wet
land rice farming. (2) The use of wet land paddy production in
Siantar Marimbunsub district had not been optimally seen from the result
of NPM / Px was not the same as one so it is necessary to increase and
decrease the use of production input. The optimal use of production factor
for labor was 110 HOK, 60,24 Kg of seed, Ureafertilizer equal to 150 Kg,
Sp36 fertilizer equal to 70 Kg, KClfertilizer equal to 67 Kg and pesticide
equal to 128,68 ml

Keywords Wet Land Paddy Farming, Productivity, Optimization

\section{PENDAHULUAN}

Pembangunan pertanian secara umum pada dasarnya merupakan bagian integral dan tidak terpisahkan dari pembangunan nasional. Pembangunan pertanian di era reformasi menempatkan petani sebagai subjek dalam rangka mencapai tujuan nasional. Tujuan pembangunan pertanian adalah memberdayakan petani menuju suatu masyarakat tani yang mandiri, maju, sejahtera dan berkeadilan. Pembangunan pertanian dapat dicapai melalui pembangunan pertanian yang berkelanjutan. Pembangunan pertanian yang berkelanjutan ditandai adanya kelangsungan produksi yang memberikan keuntungan, peningkatan produksi pertanian dan adanya kebebasan bagi petani untuk menentukan pilihan terbaik dalam berusahatani (Kurniawan, 2004). Pengembangan komoditi 


\section{JESYA}

JURNAL EKONOMI \& EKONOMI SYARIAH

Jurnal Ekonomi \& Ekonomi Syariah Vol 2 No 2, Juni 2019

E-ISSN : 2599-3410 | P-ISSN : 2614-3259

DOI : https://doi.org/10.36778/jesya.v2i2.91

tanaman pangan salah satu jenisnya adalah tanaman padi. Padi merupakan komoditi pertanian yang mempunyai arti penting bagi manusia, khususnya bagi penduduk Indonesia yang menjadikan padi sebagai makanan pokok. Komoditi tanaman padi sawah mempunyai fungsi utama sebagai penyuplai pangan nasional, dan sampai sekarang fungsi ini belum tergantikan oleh sektor lain. Mengingat sektor tanaman padi yang sangat mendukung terhadap ketahanan pangan nasional maka pengembangan tersebut sangat penting untuk dilanjutkan. Padi merupakan komoditas strategis dan utama dalam memenuhi kebutuhan pangan nasional. Hal ini disebabkan bahwa 95 persen rakyat Indonesia masih mengkonsumsi beras sebagai sumber bahan pangan karbohidrat (Ditjen Bina Produksi Tanaman Pangan, 2004). Di Kelurahan Simarimbun, lahan sawah memberi manfaat yang sangat luas terutama dalam penyediaan komoditas pangan untuk memenuhi kebutuhan pangan Kelurahan Simarimbun. Kabupaten Kelurahan Simarimbun merupakan salah satu sentra penghasil komoditi padi di Kelurahan Simarimbun. Berdasarkan Tabel 1 diatas dapat dijelaskan bahwa tingkat produksi dan luas panen padi sawah di Kelurahan Simarimbun merupakan tertinggi kedua dibandingkan dengan Kabupaten lainnya di Kelurahan Simarimbun dengan produksi mencapai 75.109 ton dan luas panen mencapai 18.322 ha, tetapi dilihat dari tingkat produktivitasnya, Kelurahan Simarimbun masih tergolong rendah dibandingkan kabupaten lainnya dengan tingkat produktivitas mencapai 4,09 ton/ha. Kelurahan Simarimbun ang memiliki kawasan dataran rendah dan tidak berbukit cocok ditanami tanaman pangan padi dan palawija lainnya dan dapat dijadikan sebagai lahan cadangan pengembangan subsector pertanian. Kelurahan Simarimbun dari tahun 2009 sampai 2011 mengalami penurunan dan pada tahun 2012 sampai 2015 luas panen, produksi dan produktivitas rata-rata padi sawah mengalami peningkatan. Hal tersebut dapat dilihat pada tahun 2010 mengalami penurunan produksi sebesar 15.172 ton dari tahun 2009, pada tahun 2011 mengalami penurunan lagi sebesar 10.622 ton. Namun pada tahun 2012 mengalami peningkatan sebesar 6.634 ton, pada tahun 2013 sebesar 7.988 ton, pada tahun 2014 sebesar 1.407 ton dan mengalami penurunan kembali tahun 2015 sebesar 28.981 ton. Turun naiknya luas panen, produksi dan produktivitas rata-rata tentunya ada pengaruh dari faktor produksi dan kondisi alam. Faktor produksi tersebut seperti lahan, tenaga kerja dan modal yang mempengaruhi produksi padi sawah di Kelurahan Simarimbun. Hal itu dikarenakan petani sebagai manajer tidak mampu mengalokasikan sumberdaya atau faktor-faktor produksi secara optimal. Berdasarkan Laporan Dinas Pertanian Tanaman Pangan (2012) penurunan luas lahan tidak mempengaruhi penurunan produksi. Hal ini dikarenakan adanya program intensifikasi seperti program pemupukan memperbaiki irigasi serta pemberantasan hama penyakit. Kecamatan Siantar Marimbun merupakan kecamatan yang pencapaian luas panen dan produksi terbesar pada tahun 2015 seluas 4.961 ha dan produksi 19.823 ton tetapi Kecamatan Siantar Marimbun merupakan kecamatan yang memiliki produktivitas yang rendah yaitu sebesar 3,99 Ton/Ha. Rendahnya Produktivitas padi sawah disebabkan oleh banyaknya kendala yang dihadapi baik teknis maupun non teknis. Dari aspek teknis yaitu teknis budidaya yang diterapkan petani dalam mengelola lahan sawah, dimana penggunaan benih dan pupuk belum sesuai dengan anjuran, serta belum adanya varietas yang dapat beradaptasi dengan baik dan berdaya hasil tinggi dengan kondisi lahan. Sedangkan dari aspek non teknis mencakup keadaan alam yang mempengaruhi keadaan air di lahan sawah (banjir). Berhasil tidaknya seorang petani dalam memperoleh produktivitas tertinggi pada usahatani padi sawah tidak terlepas dari jumlah produksi persatuan luas pada suatu musim tanam. Faktor produksi tenaga kerja dan sarana produksi (benih, pupuk, dan pestisida) akan mempengaruhi tinggi rendahnya hasil produksi usahatani padi sawah karena penggunaan faktor produksi selama proses pengelolaan usahatani padi sawah akan berpengaruh terhadap tingkat produktivitas yang dihasilkan seorang petani.

Upaya pengembangan usahatani padi sawah di Kecamatan Siantar Marimbundiharapkan akan meningkatkan taraf hidup petani setempat, serta akan memacu pertumbuhan ekonomi di Kecamatan Siantar Marimbunsecara khususnya dan Kelurahan Simarimbun secara umumnya. Maka pengembangan usahatani padi sawah harus diarahkan pada penggunaan faktor produksi yang efisien sehingga mendatangkan keuntungan bagi petani yang mengelola usahatani padi sawah. Analisis produktivitas merupakan sebuah analisis yang dapat mengetahui hubungan antara 
input yang dikorbankan dengan output yang dihasilkan dalam proses produksi serta mampu mengukur seberapa besar pengaruh penggunaan input terhadap produktivitas. Dengan menggunakan analisis produktivitas, tingkat efisiensi usahatani yang dikelola para petani juga akan dapat diukur (Soekartawi, 1994).

\section{LANDASAN TEORI}

\section{Teori Produksi Pertanian}

Produksi adalah jumlah hasil. Dalam usaha tani, guna memperoleh hasil produksi petani melakukan usaha pengkombinasian faktor-faktor produksi yang dimiliki seperti; luas tanah, modal seperti pupuk, obat-obatan, bibit dan lain-lain, tenaga kerja, keahlian. Kemudian produktivitas adalah kemampuan suatu faktor produksi, seperti luas tanah, untuk memperoleh hasil produksi per hektar. Produksi dan produktivitas ditentukan oleh banyak faktor seperti kesuburan tanah, varitas bibit yang ditanam, penggunaan pupuk yang memadai baik jenis maupun dosis, tersedianya air dalam jumlah yang cukup, teknik bercocok tananam yang tepat dan penggunaan alat-alat produksi pertanian yang memadai dan tersedianya tenaga kerja.

\section{Teorip"PopulationeTrap"}

Dua abad lalu Thomas Robert Malthus melontarkan kerisauannya apakah produksi pertanian dunia mampu memenuhi permintaan pangan penduduk? Pada 1798 Thomas Robert Malthus menulis buku "Essay on the Principle of Population "yang menganalisis tendensi universal penduduk suatu negara untuk berkembang secara deret ukur (geometris) dengan berlipat-dua setiap 30 sampai 40 tahun, kecuali jika dicegah dengan mengecilnya bahan makanan. Pada waktu yang sama karena menurunnya kenaikan hasil (diminishing return) atas faktor produksi tetap yaitu tanah, bahan makan hanya akan bertambah secara deret hitung (aritmatis). Bahkan, karena setiap anggota penduduk mengerjakan tanah yang semakin sempit, maka kontribusi marjinalnya terhadap produksi makanan menurun. Oleh karena pertumbuhan bahan makanan tidak dapat mengimbangi membengkaknya penduduk, produksi makanan per kapita cenderung turun begitu rendah sehingga menimbulkan jumlah penduduk yang hidup pada/atau sedikit di atas tingkat subsisten. Karena itu Malthus berpendapat bahwa hanya dengan cara meningkatkan derajat hidup atau mencegah kemiskinan absolut, penduduk dapat melakukan "pengendalian moral" dan membatasi keturunan.

\section{Tanah atau Luas Lahan}

Faktor produksi tanah dalam pertanian di Indonesia memiliki kedudukan yang paling penting. Mubyarto (1985) menyatakan, tanah sebagai salah satu faktor produksi yang merupakan pabrik dari hasil - hasil pertanian yaitu tempat dimana produksi terjadi dan darimana hasil produksi dihasilkan. Luas tidaknya lahan pertanian mempengaruhi besarnya tingkat hasil produksi pertanian. Sebagai faktor produksi, tanah mendapat bagian dari hasil produksi karena jasanya dalam produksi itu. Pembayaran atas jasa produksi ini disebut sewa tanah (rent). Menurut David Ricardo (dikutip dari Mubyarto,1985), tinggi rendahnya sewa tanah disebabkan oleh perbedaan kesuburan tanah dan sewa tanah dapat naik atau turun mempunyai hubungan langsung dengan komoditi yang diproduksikan dari tanah. Semakin tinggi harga beras makin tinggi sewa tanah dan sebaliknya.

\section{Teori Konsumsi}

Konsumsi merupakan segala kegiatan yang digunakan dengan tujuan untuk mengambil kegunaan pada suatu produk dan jasa. Produk dan jasa ini dapat berupa barang atau benda, serta sebuah jenis jasa atau pelayanan. Kegiatan konsumsi bertujuan untuk memenuhi semua kebutuhan yang bersifat penting atau bahkan hanya bersifat kesenangan atau kepuasan dalam waktu seketika. Dalam teori konsumsi Keynes menyatakan bahwa besar kecilnya pengeluaran konsumsi (C) didasarkan atas besar kecilnya pendapatan (Y) masyarakat. Konsmsi dan pendapatan disebut Keynes sebagai Marginal Propensity to Consume (MPC). MPC ini digunakan untuk mengukur bahwa semakin besar pendapatan yang dimiliki, maka tingkat konsumsi rumah tangga juga tinggi, dan begitu pula sebaliknya. Untuk menjelaskan teori Keynes tersebut, maka perlu dibuat rancangan perhitungan pendapatan dan konsumsi melalui Teori Konsumsi dengan Hipotesis Pendapatan Absolut. Teori tersebut menyatakan bahwa jumlah pengeluaran konsumsi berkaitan erat dengan pendapatan negara yaitu dapat mempengaruhi fluktuasi perekonomian negara, dimana hal tersebut dapat diukur 
berdasarkan harga konstan. Fungsi Konsumsi Keynes adalah: $\mathrm{C}=\mathrm{Co}=\mathrm{cYd}$. Dimana: $\mathrm{Co}=$ Konsumsi otonom (The Autonomus Consumption) $\mathrm{Yd}=$ Pendapatan yang bisa digunakan untuk konsumsi. Rumus $\mathrm{Yd}=\mathrm{Y}-\mathrm{Tx}+\mathrm{Tr}$. Dimana $\mathrm{Tx}=$ Pajak $\mathrm{Tr}=$ Subsidi atau transfer. 18 Dari rumus tersebut dapat diperoleh rata-rata konsumsi atau Average Propensity to Consume (APC) yaitu perbandingan jumlah konsumsi dibandingkan dengan pendapatan. Kemudian jika terjadi perubahan yaitu tambahan pendapatan sehingga menambah jumlah konsumsi, maka dapat dihitung dengan Marginal Propensity to Consume atau perubahan konsumsi yang terjadi karena pendapatan yang meningkat.

\section{METODE PENELITIAN}

Penelitian ini dilakukan untuk mengetahui faktor- faktor ang mempengaruhi produkivitas usaha tani padi sawah, untuk mengetahui tingkat optimal penggunaan faktor-faktor produksi pada usahatani padi sawah di Kelurahan Simarimbun. Adapun data tesebut antara lain: jumlah tenaga kerja yang dicurahkan, jumlah benih, jumlah pupuk dan jumlah pestisida.

Metode Analisis Data

Metode analisis data adalah metode tabulasi data yaitu dari data kuesioner disusun sesuai dengan klasifikasi jenis data. Analisis data yang digunakan untuk mengetahui tingkat produktivitas usaha tani padi sawah adalah dengan menghitung nilai produktivitas Untuk menganalisa faktorfaktor yang mempengaruhi produktivitas usahatani padi sawah digunakan analisis regresi linier berganda dengan bentuk umum (Soekartawi, 1994) sebagai berikut : Y = F (X1, $\mathrm{X} 2, \ldots, \mathrm{Xn}) \mathrm{e}$

Fungsi matematisnya adalah :

$\mathrm{Y}=\mathrm{B} 0+\mathrm{B} 1 \mathrm{X} 1+\mathrm{B} 2 \mathrm{X} 2+\mathrm{B} 3 \mathrm{X} 3+\mathrm{B} 4 \mathrm{X} 4+\mathrm{B} 5 \mathrm{X} 5+\mathrm{B} 6 \mathrm{X} 6+\mathrm{D}+\mathrm{e}$

Dimana :

$\mathrm{Y}=$ Produktivitas Padi Sawah $(\mathrm{Kg} / \mathrm{Ha})$

$\mathrm{X} 1$ = Penggunaan tenaga kerja $(\mathrm{HOK} / \mathrm{Ha}) \mathrm{X} 2$

$\mathrm{X} 3$ = Penggunaan pupuk Urea $(\mathrm{Kg} / \mathrm{Ha})$

$\mathrm{X} 4$ = Penggunaan pupuk SP36 $(\mathrm{Kg} / \mathrm{Ha}) \mathrm{X} 5$

$\mathrm{X} 6$ = Penggunaan pestisida $(\mathrm{ml} / \mathrm{Ha}) \mathrm{D}$

B0 = Intercept

$\mathrm{B} 1 \ldots \mathrm{Bn} \quad=$ Koefisien Regresi

$\mathrm{e}=$ Faktor pengganggu

Untuk mengetahui besarnya sumbangan setiap variabel terhadap produktivitas usahatani padi sawah atau apakah hasil pendugaan bidang regresi tersebut cukup baik.

\section{HASIL PEMBAHASAN}

Identitas Petani Sampel

Identitas petani sampel memberikan gambaran tentang keadaan petani sebagai salah satu faktor penting dalam usahatani. Petani dalam suatu usahatani adalah sebagai pengelola yang merencanakan,mengorganisir, melaksanakan serta mengevaluasi suatu proses produksi. Identitas petani sampel dalam penelitian ini adalah identitas petani di Desa Rantau Makmur dan Desa Sungai Rambut Kecamatan Siantar Marimbun Kelurahan Simarimbun yang meliputi : umur, pendidikan, jumlah anggota keluarga, luas lahan Analisis Regresi Faktor-faktor Yang Mempengaruhi Produktivitas Padi Sawah

Dalam penelitian ini beberapa faktor yang diduga berpengaruh terhadap produktivitas usahatani padi sawah adalah tenaga kerja yang dicurahkan, penggunaan benih, penggunaan pupuk urea, pupuk sp36, pupuk $\mathrm{KCl}$, penggunaan pestisida, dan Dummy. Variabel bebas (independent variable) yang dianalisis adalah terdiri dari tenaga kerja yang dicurahkan (X1), penggunaan benih (X2), penggunaan pupuk Urea (X3), penggunaan pupuk Sp36 (X4), penggunaan pupuk $\mathrm{KCl}(\mathrm{X} 5)$, penggunaan pestisida (X6) dan Dummy serta variabel terikat (dependent variable) adalah produktivitas usahatani padi sawah $(\mathrm{Y})$. Uji koefisien determinasi digunakan untuk mengetahui seberapa besar proporsi dari faktor produksi berpengaruh terhadap produktivitas. Hasil analisis 


\section{JESYA}

JURNAL EKONOMI \& EKONOMI SYARIAH

Jurnal Ekonomi \& Ekonomi Syariah Vol 2 No 2, Juni 2019

E-ISSN : 2599-3410 | P-ISSN : 2614-3259

DOI : https://doi.org/10.36778/jesya.v2i2.91

dapat dilihat pada nilai Adjusted R-squared sebesar 0,8442. Hal ini berarti 84,42 persen variasi hasil produktivitas usahatani padi sawah dipengaruhi oleh faktor produksi yang terdapat dalam model, sedangkan sisanya sebesar 15,58 persen dipengaruhi oleh faktor lain di luar model.

Pengaruh Penggunaan Faktor Produksi Terhadap Produktivitas Usahatani Padi Sawah.

Untuk menguji variabel-variabel secara bersama-sama terhadap produktivitas usahatani padi sawah yang dihasilkan dapat diketahui dengan menggunakan uji $\mathrm{F}$, dari hasil analisis diperoleh nilai pada F-statistic sebesar 68,93 dengan probabilitas sebesar 0,000000. Nilai probabilitas yang lebih kecil dari alfa $(0,05)$ menunjukkan hasil yang signifikan, artinya variabel bebas yang terdapat dalam model secara bersama-sama berpengaruh terhadap produktivitas padi sawah di Kecamatan Siantar Marimbun Pengaruh faktor produksi terhadap produktivitas padi sawah secara parsial dapat diketahui dengan melihat nilai probabilitas pada masing-masing variabel faktor produksi. Nilai probabilitas yang lebih kecil dari alfa $(0,05)$ menunjukkan hasil yang signifikan pada tingkat kepercayaan 95 persen. Berdasarkan hasil analisis diatas, didapat bahwa nilai probabilitas penggunaan benih (X2), penggunaan pupuk Urea (X3), penggunaan pupuk SP36 (X4), penggunaan pupuk KCl (X5) dan Dummy Sistem Pertanaman (D) lebih kecil dari alfa $(0,05)$ pada tingkat kepercayaan 95 persen, yang berarti secara parsial atau individu variabel bebas tersebut berpengaruh nyata terhadap produktivitas usahatani padi sawah. Sedangkan nilai probabilitas penggunaan tenaga kerja (X1) dan penggunaan pestisida lebih besar dari alfa $(0,05)$ pada tingkat kepercayaan 95 persen, yang berarti secara parsial atau individu variabel bebas tersebut tidak berpengaruh nyata terhadap produktivitas usahatani padi sawah.

Pengaruh Penggunaan Faktor Produksi Tenaga Kerja (X1) Terhadap Produktivitas

Usahatani Padi Sawah

Rata-rata tenaga kerja pada usahatani padi sawah per musim tanamnya di daerah penelitian adalah 98,53 HOK / Ha. Berdasarkan hasil regresi fungsi produksi Cobb Douglass dapat ditentukan bahwa penggunaan variabel tenaga kerja (X1) mempunyai koefisien sebesar 35,62 yang berpengaruh positif, artinya apabila penggunaan faktor produksi tenaga kerja (X1) bertambah 1 persen, maka produktivitas usahatani padi sawah akan bertambah sebesar 35,62 persen. Taraf signifikansi tenaga kerja (X1) sebesar 0,8895 lebih besar dari 0,05 yang artinya tidak signifikan secara statistik terhadap produktivitas usahatani padi sawah. Dari hasil tersebut menunjukkan bahwa penambahan curahan tenaga kerja (X1) didaerah penelitian secara individu tidak berpengaruh nyata terhadap produktivitas usahatani padi sawah.

Sejalan dengan penelitian (Hia, J. 2009) bahwa banyaknya curahan tenaga kerja tidak selamanya berpengaruh dan berpengaruh positif terhadap produktivitas. Sebaliknya, penggunaan jumlah tenaga kerja dengan jumlah yang tidak sesuai dengan keperluan, bisa mengakibatkan pengaruh yang negatif terhadap produktivitas. Keberhasilan produktivitas tidak semata dipengaruhi oleh curahan tenaga kerja, namun lebih dipengaruhi oleh keterampilan dan motivasi kerja yang dimiliki oleh tenaga kerja itu sendiri, termasuk di dalamnya faktor budaya yang kurang mendukung, misalnya kurang motivasi untuk bekerja dengan baik agar mendapatkan hasil usahatani yang maksimal.

Pengaruh Penggunaan Faktor Produksi Benih (X2) Terhadap Produktivitas Usahatani Padi Sawah Rata-rata penggunaan faktor produksi benih oleh petani di daerah penelitian pada usahatani padi sawah sebesar 53,52 Kg per hektar. Berdasarkan hasil regresi fungsi produksi Cobb Douglass dapat ditentukan bahwa variabel penggunaan faktor produksi benih (X2) mempunyai koefisien sebesar 2,20 yang berpengaruh positif, artinya apabila penggunaan faktor produksi benih (X2) bertambah 1 persen, maka produktivitas usahatani padi sawah akan bertambah sebesar 2,20 persen. Taraf signifikansi benih (X2) sebesar 0,0000 lebih kecil dari 0,05 yang artinya signifikan secara statistik terhadap produksi usahatani padi sawah. Dari hasil tersebut menunjukkan bahwa penambahan jumlah penggunaan faktor produksi benih (X2) didaerah penelitian secara individu berpengaruh nyata terhadap produktivitas usahatani padi sawah.

Menurut Balai Penelitian Tanaman Padi Sawah Pusat Penelitian dan 
Pengembangan Tanaman Pangan (2007), rata-rata penggunaan benih sebanyak $20-35 \mathrm{Kg} / \mathrm{Ha}$. Hal ini menunjukkan bahwa variabel faktor produksi benih secara parsial, berpengaruh nyata terhadap produksi usahatani padi sawah. Benih yang bermutu menjanjikan produksi yang baik dan bermutu pula jika diikuti dengan perlakuan agronomi yang baik dan input teknologi yang berimbang. Sebaliknya, bila benih yang digunakan tidak berkualitas baik maka produksinya banyak tidak menjanjikan atau tidak lebih baik dari penggunaan benih bermutu. Penggunaan benih berkualitas diharapkan mampu mengurangi berbagai faktor resiko kegagalan panen. Ini sejalan dengan penelitian (Venitasari, R. 2009) bahwa semakin banyak jumlah benih padi yang digunakan maka produktivitas akan semakin meningkat dengan batas jumlah rumpun perlubang tidak ditentukan dan disesuaikan dengan luas usahatani yang dimiliki oleh masing-masing petani.

Pengaruh Penggunaan Faktor Produksi Pupuk Urea (X3) Terhadap Produktivitas Usahatani Padi Sawah.

Rata-rata penggunaan pupuk urea oleh petani di daerah penelitian terhadap tanaman padi sawah sebesar 120,41 Kg per hektar. Berdasarkan hasil regresi fungsi produksi Cobb Douglass dapat ditentukan bahwa variabel penggunaan faktor produksi pupuk urea (X3) mempunyai koefisien sebesar 5,20 yang berpengaruh positif, artinya apabila penggunaan pupuk urea (X3) bertambah 1 persen, maka produktivitas usahatani padi sawah akan bertambah sebesar 5,20 persen. Taraf signifikansi penggunaan pupuk urea (X3) yaitu sebesar 0,0014 lebih kecil dari 0,05 yang artinya signifikan secara statistik terhadap produksi usahatani padi sawah. Dari hasil tersebut menunjukkan bahwa penambahan jumlah penggunaan pupuk urea (X3) di daerah penelitian secara individu berpengaruh nyata terhadap produktivitas usahatani padi sawah.

Sejalan dengan hasil penelitian (Junaidi, D. 2001) bahwa penggunaan pupuk yang semakin banyak (sesuai dengan kebutuhan dan dosis) akan meningkatkan produktivitas. Hal ini terjadi dengan penelitian ini sebagaimana didapat apabila pupuk yang digunakan sesuai dengan kebutuhan dan dosis yang sesuai di daerah penelitian dan dapat lebih dioptimalkan, maka hal ini akan dapat meningkatkan produktivitas padi sawah.

Pengaruh Penggunaan Faktor Produksi Pupuk Sp36 (X4) Terhadap Produktivitas Usaha tani Padi Sawah

Rata-rata penggunaan pupuk sp36 oleh petani di daerah penelitian terhadap tanaman padi sawah sebesar 95,60 Kg per hektar. Berdasarkan hasil regresi fungsi produksi Cobb Douglass dapat ditentukan bahwa variabel penggunaan faktor produksi pupuk sp36 (X4) mempunyai koefisien sebesar 11,05 yang berpengaruh positif, artinya apabila penggunaan pupuk sp36 (X4) bertambah 1 persen, maka produktivitas usahatani padi sawah akan bertambah sebesar 11,05 persen. Taraf signifikansi penggunaan pupuk sp36 (X4) yaitu sebesar 0,0000 lebih kecil dari 0,05 yang artinya signifikan secara statistik terhadap produksi usahatani padi sawah. Dari hasil tersebut menunjukkan bahwa penambahan jumlah penggunaan pupuk sp36 (X4) di daerah penelitian secara individu berpengaruh nyata terhadap produktivitas usahatani padi sawah.

Pengaruh Penggunaan Faktor Produksi Pupuk KCl (X5) Terhadap Produktivitas Usahatani Padi Sawah

Rata-rata penggunaan pupuk $\mathrm{KCl}$ oleh petani di daerah penelitian terhadap tanaman padi sawah sebesar $69,51 \mathrm{Kg}$ per hektar. Berdasarkan hasil regresi fungsi produksi Cobb Douglass dapat ditentukan bahwa variabel penggunaan faktor produksi pupuk $\mathrm{KCl}$ (X5) mempunyai koefisien sebesar 3,48 yang berpengaruh positif, artinya apabila penggunaan pupuk $\mathrm{KCl}$ (X5) bertambah 1 persen, maka produktivitas usahatani padi sawah akan bertambah sebesar 3,48 persen. Taraf signifikansi penggunaan pupuk $\mathrm{KCl}(\mathrm{X} 5)$ yaitu sebesar 0,0000 lebih kecil dari 0,05 yang artinya signifikan secara statistik terhadap produksi usahatani padi sawah. Dari hasil tersebut menunjukkan bahwa penambahan jumlah penggunaan pupuk $\mathrm{KCl}$ (X5) di daerah penelitian secara individu berpengaruh nyata terhadap produktivitas usahatani padi sawah. 


\section{JESYA}

JURNAL EKONOMI \& EKONOMI SYARIAH

Jurnal Ekonomi \& Ekonomi Syariah Vol 2 No 2, Juni 2019

E-ISSN : 2599-3410 | P-ISSN : 2614-3259

DOI : https://doi.org/10.36778/jesya.v2i2.91

Pengaruh Penggunaan Faktor Produksi Pestisida (X6) Terhadap Produktivitas Usahatani

Padi Sawah

Rata-rata penggunaan pestisida oleh petani di daerah penelitian terhadap tanaman padi sawah sebesar 704,70 ml per hektar. Berdasarkan hasil regresi fungsi Cobb Douglass dapat ditentukan bahwa variabel pengunaan faktor produksi pestisida (X6) mempunyai koefisien sebesar -6,96 yang berpengaruh negatif, artinya apabila penggunaan pestisida bertambah 1 persen, maka produksi usahatani padi sawah akan berkurang sebesar 6,96 persen. Taraf signifikansi penggunaan pestisida (X6) sebesar 0,9531 lebih besar dari 0,05 yang artinya tidak signifikan secara statistik terhadap produktivitas usahatani padi sawah. Dari hasil tersebut menunjukkan bahwa penambahan jumlah penggunaan pestisida (X6) di daerah penelitian secara individu tidak berpengaruh nyata terhadap produktivitas usahatani padi sawah. Ini sejalan dengan penelitian (Harya, R. 2008) yang dihubungkan dengan tingkat pendidikan petani yang relatif masih rendah sehingga kurangnya pengetahuan petani dalam penggunaan dosis, waktu dan jenis pestisida yang tepat bagi kebutuhan tanaman yang diusahakan mengingat kondisi usahatani padi di daerah penelitian ini juga tidak banyak mengalami gangguan hama dan penyakit, sehingga berapapun jumlah pestisida yang digunakan petani tidak terlalu berpengaruh terhadap produktivitas usahatani padi sawah.

\section{Pengaruh Dummy Sistem Tanam (TAPIN dan TABELA) Terhadap Produktivitas} Usahatani Padi Sawah

Berdasarkan hasil regresi fungsi Cobb Douglass dapat ditentukan bahwa Sistem Pertanaman (D) mempunyai koefisien sebesar 3,94 yang berpengaruh positif, artinya apabila Sistem Pertanaman bertambah 1 persen, maka produktivitas usahatani padi sawah akan bertambah sebesar 3,94 persen. Taraf signifikansi Sistem Pertanaman (D) sebesar 0,0000 lebih kecil dari 0,05 yang artinya signifikan secara statistik terhadap produktivitas usahatani padi sawah. Dari hasil tersebut menunjukkan bahwa Sistem Pertanaman (D) di daerah penelitian secara individu berpengaruh nyata terhadap produktivitas usahatani padi sawah.

\section{Optimalisasi Penggunaan Input Produksi pada Usahatani Padi Sawah}

Untuk mengetahui tingkat optimasi penggunaan input produksi pada usahatani padi sawah dilakukan melalui pendekatan pencapaian keuntungan maksimum dimana Nilai Produk Marjinal (NPM) yang dibandingan terhadap harga satuan input produksi atau Biaya Korbanan Marjinal (Px). Dimana Nilai Produk Marjinal atau NPM merupakan perkalian antara Produk Marjinal (PM) dengan harga produk per satuannya (merupakan harga produk per satuan) dan harga satuan input produksi merupakan harga rata-rata input produksi per satuan.

Keuntungan maksimum tercapai apabila dimana kondisi produksi berada pada titik optimum (NPM / Px = 1). Produksi optimum merupakan kondisi dimana semua faktor produksi dikombinasikan pada tingkat optimum. Tingkat optimasi penggunaan input produksi dapat tercapai apabila rasio antara keduanya mempunyai nilai sama dengan satu (NPM / Px $=1)$. Semakin dekat dengan nilai satu maka dapat dikatakan bahwa penggunaan sudah relatif lebih optimum dan apabila nilainya kurang dari satu berarti sudah tidak optimum lagi. Perhitungan penentuan tingkat optimasi penggunaan input-input produksi yang digunakan pada usahatani padi sawah diperoleh dari perhitungan elastisitas produksi (bi) yaitu : Rasio antara NPM dan Px yang terlihat pada Tabel 19 di atas menunjukkan penggunaan faktor produksi pada usahatani padi sawah belum memiliki keuntungan maksimum. Rasio NPM dan Px untuk faktor produksi usahatani padi sawah yakni tenaga kerja dan pupuk urea menghasilkan nilai lebih dari satu yang memiliki arti bahwa kondisi optimal belum tercapai dan perlu penambahan pemakaian faktor produksi untuk mencapai kondisi optimal. Tambahan manfaat yang diperoleh dari peningkatan penggunaan faktor produksi masih lebih besar dari tambahan biaya.

Rasio NPM dan Px untuk faktor produksi benih, pupuk Sp36, pupuk $\mathrm{KCl}$ dan pestisida bernilai negatif berari rasio NPM dan Px kurang dari satu. Angka negatif berasal dari koefisien regresi yang dihasilkan bernilai negatif. Penggunaan faktor produksi benih, pupuk Sp36, pupuk $\mathrm{KCl}$ dan pestisida berada dalam kondisi yang telah melampaui optimal dan perlu pengurangan 
penggunaan faktor produksi. Nilai produk marjinal setiap penambahan faktor produksi tersebut ke dalam proses produksi akan selalu lebih kecil daripada biaya produk marjinalnya sama artinya tambahan manfaat yang diperoleh dari penambahan penggunaan faktor produksi tersebut akan selalu lebih kecil dari tambahan biaya.

Penggunaan faktor produksi tenaga kerja pada usahatani padi sawah di daerah penelitian rata-rata sebanyak 98,53 HOK per satu siklus proses produksi usahatani padi sawah. Upah tenaga kerja diperhitungkan rata-rata sebesar Rp 65.000,00 per orang diperoleh rasio NPM dan Px sebesar 7,38. Secara teknis, penggunaan tenaga kerja pada proses usahatani padi sawah belum efisien karena produksi berada pada daerah irasional. Secara ekonomis, penggunaan tenaga kerja belum optimal dan perlu penambahan tenaga kerja hingga tercapai kondisi optimal. Penggunaan tenaga kerja belum optimal disebabkan karena banyaknya proses produksi usahatani yang terpotong seperti tidak melakukan pengolahan lahan dengan baik, hal lainnya yaitu masih adanya tenaga kerja yang melakukan pekerjaan rangkap seperti menugal tanah dan menabur atau memasukkan benih ke dalam lubang tugalan dilakukan oleh satu orang. Tenaga kerja baru masih dibutuhkan agar setiap tenaga kerja membidangi satu pekerjaan. Besarnya nilai input produksi tenaga kerja (X1) yang harus digunakan petani agar tercapai keunntungan maksimum dengan rasio NPM dan Px sama dengan satu adalah 110 HOK.

Penggunaan faktor produksi benih pada usahatani padi sawah di daerah penelitian rata-rata sebanyak 53,52 Kg. Harga beli benih padi sawah tersebut adalah Rp 15.000,00 per Kg, sehingga diperoleh rasio NPM dan Px sebesar -12,77. Secara teknis, penggunaan faktor produksi benih tidak mencapai tingkat efisien karena prooduksi berada pada daerah irasional (tahap kenaikan hasil yang semakin bertambah). Namun secara ekonomis, penggunaan benih telah melampaui batas optimal sehingga perlu dikurangi penggunaannya hingga batas optimal. Penyebab terlampuinya batas optimal penggunaan faktor produksi benih pada usahatani padi sawah di daerah penelitian adalah karena petani di daerah penelitian banyak yang menggunakan sistem tabur benih langsung (TABELA) yang mana dalam pelaksanaan proses penaburan benih tersebut petani menabur hingga permukaan tanah rapat ditanami benih. Besarnya nilai input produksi benih (X2) yang harus digunakan petani agar tercapai keunntungan maksimum dengan rasio NPM dan Px sama dengan satu adalah $45 \mathrm{Kg}$.

Faktor produksi pupuk urea yang digunakan pada usahatani padi sawah di daerah penelitian dalam satu kali proses produksi di tahun 2016 rata-rata 120,41 Kg. Harga per kilogram pupuk urea yang digunakan Rp 3.000,00 sehingga diperoleh rasio NPM dan Px sebesar 218,41. Secara teknis, penggunaan faktor produksi pupuk urea tidak mencapai tingkat efisien karena produksi berada pada daerah irasional. Secara ekonomis, penggunaan pupuk urea belum optimal sehingga perlu ditambahkan penggunaannya hingga batas optimal. Besarnya nilai input produksi pupuk urea (X3) yang harus digunakan petani agar tercapai keunntungan maksimum dengan rasio NPM dan Px sama dengan satu adalah $150 \mathrm{Kg}$.

Faktor produksi pupuk Sp36 yang digunakan pada usahatani padi sawah di daerah penelitian dalam satu kali proses produksi di tahun 2016 rata-rata $95,90 \mathrm{Kg}$. Harga per kilogram pupuk Sp36 yang digunakan $\mathrm{Rp} 3.500,00$ sehingga diperoleh rasio NPM dan Px sebesar -86,55. Secara teknis, penggunaan faktor produksi pupuk Sp36 tidak mencapai tingkat efisien karena produksi berada pada daerah irasional (tahap kenaikan hasil yang semakin bertambah). Namun secara ekonomis, penggunaan pupuk Sp36 telah melampaui batas optimal sehingga perlu dikurangi penggunaannya hingga batas optimal. Penyebab terlampuinya batas optimal penggunaan faktor produksi pupuk pada usahatani padi sawah di daerah penelitian adalah banyaknya anggapan petani bahwa ketika banjir menggenangi lahan sawah petani, pupuk yang mereka berikan untuk tanaman padi sawah tidak terserap dengan baik sehingga petani terus menerus memberikan pupuk. Besarnya nilai input produksi pupuk Sp36 (X4) yang harus digunakan petani agar tercapai keunntungan maksimum dengan rasio NPM dan Px sama dengan satu adalah $70 \mathrm{Kg}$.

Faktor produksi pupuk $\mathrm{KCl}$ yang digunakan pada usahatani padi sawah di daerah penelitian dalam satu kali proses produksi di tahun 2016 rata-rata $69,51 \mathrm{Kg}$. Harga per kilogram pupuk $\mathrm{KCl}$ yang digunakan $\mathrm{Rp} 4.000,00$ sehingga diperoleh rasio NPM dan Px sebesar -72,73. Secara teknis, 
penggunaan faktor produksi pupuk $\mathrm{KCl}$ tidak mencapai tingkat efisien karena produksi berada pada daerah irasional. Namun secara ekonomis, penggunaan pupuk KCl telah melampaui batas optimal sehingga perlu dikurangi penggunaannya hingga batas optimal. Besarnya nilai input produksi pupuk $\mathrm{KCl}(\mathrm{X} 5)$ yang harus digunakan petani agar tercapai keunntungan maksimum dengan rasio NPM dan Px sama dengan satu adalah $67 \mathrm{Kg}$. Penggunaan faktor produksi pestisida pada usahatani padi sawah di daerah penelitian rata-rata sebanyak 704,70 ml. Harga jual pestisida per mililiternya adalah sebesar Rp 300 sehingga diperoleh rasio antara NPM dan Px sebesar -185,93.

Secara teknis, penggunaan faktor produksi pestisida tidak mencapai tingkat efisien karena produksi berada pada daerah irasional. Namun secara ekonomis, penggunaan pestisida telah melampaui batas optimal sehingga perlu dikurangi penggunaannya hingga batas optimal. Besarnya nilai input produksi pestisida (X6) yang harus digunakan petani agar tercapai keunntungan maksimum dengan rasio NPM dan Px sama dengan satu adalah 127,68 ml.

\section{KESIMPULAN}

Penggunaan faktor produksi mempengaruhi $84,42 \%$ produktivitas padi sawah yang ditunjukkan oleh nilai koefisien determinasi (R2) dengan nilai sebesar 0,8442 . Hal ini berarti bahwa produktivitas padi sawah (Y) dapat dijelaskan oleh variabel tenaga kerja (X1), benih (X2), pupuk urea (X3), pupuk Sp36 (X4), pupuk KCl (X5), pestisida (X6) dan Dummy (Sistem tanam TAPIN dan TABELA) sebesar $84,42 \%$ sedangkan sisanya $15,58 \%$ dipengaruhi oleh faktor lainnya yang tidak dijelaskan dalam penelitian ini. Hasil regresi diperoleh bahwa faktor produksi pada usahatani padi sawah secara bersama-sama berpengaruh terhadap produktivitas usahatani padi sawah. Secara parsial hasil regresi diperoleh bahwa pada usahatani padi sawah penggunaan faktor produksi tenaga kerja dan pestisida tidak berpengaruh secara signifikan terhadap produktivitas usahatani padi sawah. Sementara penggunaan faktor produksi benih, pupuk urea, pupuk sp36, dan pupuk $\mathrm{KCl}$ berpengaruh signifikan terhadap produktivitas usahatani padi sawah.

Optimalisasi penggunaan faktor-faktor produksi terhadap produksi dalam usahatani padi sawah di Kecamatan Siantar Marimbun, didapat hasil bahwa penggunaan faktor produksi pada usahatani padi sawah belum optimal dan sebagian besar tidak optimal sehingga perlu dilakukan penambahan dan pengurangan penggunaan input produksi. Penggunaan faktor produksi yang belum optimal adalah tenaga kerja (X1) sebesar 98,53 HOK dan pupuk urea (X3) sebesar 120,41 $\mathrm{Kg}$ sehingga perlu penambahan penggunaan faktor produksi menjadi $110 \mathrm{HOK}$ untuk tenaga kerja dan $150 \mathrm{Kg}$ untuk pupuk urea agar mencapai kondisi optimal. Penggunaan faktor produksi yang tidak optimal adalah benih (X2) sebesar 53,52 Kg, pupuk Sp36 (X4) sebesar 95,60 Kg, pupuk KCl (X5) sebesar $69,51 \mathrm{Kg}$ dan pestisida sebesar 704,70 $\mathrm{Kg}$ sehingga perlu pengurangan penggunaan faktor produksi benih menjadi $45 \mathrm{Kg}$, pupuk sp36 menjadi $70 \mathrm{Kg}$, pupuk $\mathrm{KCl}$ menjadi $67 \mathrm{Kg}$ dan pestisida menjadi $127,68 \mathrm{ml}$.

\section{REFERENSI}

[1] Hia J. 2009. Analisis Produktivitas Usahatani Padi Sawah di Kabupaten Muaro Jambi. Skripsi Fakultas Pertanian, Universitas Jambi

[2] Junaidi D. 2001. Analisis Faktor-faktor yang Mempengaruhi Produktivitas Usahatani Padi Sawah di Desa Surabaya Kecamatan Teluk Segara Kota Bengkulu. Skripsi Fakultas Pertanian UNIB.

[3] Kurniawan F. 2004. Budidaya Tanaman Sistem Tabela. PT. Agroekatama. Bogor.

Soekartawi.1994. Teori Ekonomi Produksi. Dengan Pokok Bahasan Analisis Fungsi CoubbDouglas. PT. Raja Grafindo Persada. Jakarta. 